\title{
Learning from the douar. Michel Écochard and the modern invention of the semi-rural Moroccan habitat
}

\author{
Edoardo L. G. Bernasconi ${ }^{1,1}$ \\ ${ }^{1}$ Independent scholar
}

\begin{abstract}
At the end of WWII, after roughly thirty years of French colonialism, Morocco was facing a tremendous economic boom, but also an alarming rural exodus to the industrial cities on the coast which, in turn, had to deal with overpopulation and the phenomenon of the bidonvilles. At first, the article retraces the studies on traditional Moroccan urban, semi-rural, and rural settlements, carried out by Michel Écochard at the Service de l'Urbanisme from 1957 to 1951. Learning from local dwelling customs, the Service conceived a modern urban block model aimed at bringing wholesomeness to urban bidonvilles, as well as modernity in the countryside to stem the migrations. The essay then analyses the Service's typological studies on the courtyard housing unit, the basic cell of the urban fabric, and compares this with analogous coeval designs, influenced by Écochard's ideas, realized both in Morocco and worldwide. The final goal is to form a genealogy of architectural designs that, reinterpreting from time to time the courtyard house, can show the existence of a direct relationship between rural landscape, dwelling modes, and modern architecture.
\end{abstract}

\section{Introduction}

In an article published in L'Architecture d'Aujourd'hui in 1955 [1], the French landscape designer and urban planner Élie Mauret ${ }^{2}$ clearly described how three decades of ineffective French colonial government policies ${ }^{3}$ had led to a crisis of Morocco's cities and to the abandonment of its countryside. According to Mauret, the first mistake was the rescinding of the fragile millenary socio-economic balance between cities, douars ${ }^{4}$, and nomadic peoples, encouraging reckless

\footnotetext{
${ }^{1}$ Corresponding author: edoardoluigi.bernasconi@mail.polimi.it

${ }^{2}$ Who worked for the Service de l'Urbanisme in Morocco from 1952 until 1956 [2].

${ }^{3}$ The French Protectorate officially began with the signing of the Fez treaty on April $17^{\text {th }}, 1912$.

${ }^{4}$ The expression douar derives from the Arabic word دُوّاز $[\mathrm{dwa}: \mathrm{R}]$, originally meaning a tent camp organized in a circle. During the colonial era, the term came to mean a "group of dwellings, fixed or mobile, temporary or permanent, gathering a group of individuals sharing
} 
development of the metropolises along the coast and, secondly, having disregarded adequate territorial administration.

\section{The background: housing the Greatest Number}

In 1912, the first Resident-General of Morocco, Louis Hubert Gonzalve Lyautey ${ }^{5}$, issued a series of decrees to regulate construction of new cities needed to host the burgeoning European population. These measures highlighted the intention to keep the new neighborhoods and the old medinas separate. Moreover, from the one hand Lyautey wished to build the European sectors according to the most advanced urban theories, on the other he imposed strict constraints on the old towns and the architectural heritage to protect local culture and traditions [3].

Yet, in formulating these provisions, he underestimated the consequences of the internal social upheavals that would result from importing the new economic system. Over time, in fact, the industrial development produced a disproportionate mass migration to the large cities [4]. Very soon, the production zones, deprived of new neighborhoods for the natives or of modernized medinas that might have absorbed such an increase in population, would find themselves surrounded by vast bidonvilles.

Actually, the issue of housing the masses was one of the predominant topics of the $20^{\text {th }}$ century's international architectural debate. The $2^{\text {nd }} \mathrm{CIAM}$, held in Frankfurt in 1929, was entitled "The Dwelling for Minimal Existence". In those same years, the socialist administration of Vienna built the first modern apartment blocks, and from the end of WWII until the late 1960s, the issue gained increasing relevance for its relationship with the dilemma of suburb sprawl. These theories found fertile application in the colonized territories of North Africa. In this case, the administrations were motivated by the dual objective of housing those who had moved from rural territories to the industrial cities, and of promulgating an idea of imported civilization, considered more advanced.

In 1913, Lyautey appointed Henri Prost ${ }^{6}$ head of the Service spécial d'architecture et des plans des villes and tasked him with developing an expansion plan for Casablanca ${ }^{7}$. In keeping with Lyautey's ideas, this modern design did not touch the old town and kept the new residential sectors separate for ethnic reasons. With the need to define a site to house the new Muslim citizens, Prost planned to build a "New Medina" on land belonging to the Habous $^{8}$. In 1917, Albert Laprade ${ }^{9}$ began constructing a neighborhood for low-

\footnotetext{
a kinship, founded upon a common ancestry of paternal line". Le Trésor de la Langue Française informatisé, retrieved from: http://www.cnrtl.fr/definition/douar.

${ }^{5}$ Nancy 1854 - Theorey-Lyautey 1934, Minister of War during WWI, French marshal from 1912, Moroccan Resident-General from 1912 until 1925.

${ }^{6}$ Paris 1874-1959, French architect and urban planner.

${ }^{7}$ Prost's design shows how Morocco and the colonies were often considered a boot-camp for the most advanced architectural and urban theories. In fact, his plan was structured on the principles of zoning, rational use of land, alignments, and land ownership redistribution. The same concepts would not find an application in Europe until after WWI [5].

${ }^{8}$ According to Islamic law, these are pious associations that possess inalienable lands.

${ }^{9}$ Buzançais 1883 - Paris 1978, French architect.
} 
income Muslims, inspired by observations made during his explorations throughout the country ${ }^{10}$.

Aside from the "arabesque" character of the whole neighborhood, the residential units were conceived on the traditional courtyard house model. However, rather than examining typological problems, the objective was to revisit the figurative language of the medina to encourage a gradual transition from a traditional lifestyle to a more modern one. Nevertheless, the plan for the Habous neighborhood marked the start of a design tradition for new Muslim workingclass suburban neighborhoods based on a rationalization of the traditional courtyard house [6].

\section{The traditional rural courtyard house in Morocco's urban fabric}

As is known, the introverted house type organized around a central open space, originated with the very act of dwelling. Like the primitive hut, this anthropic spatial configuration provides both shelter and protection from terrestrial threats. Unlike the hut, the courtyard house also carries light and air into the roofed rooms and organizes household life in a space that is both open and private. Over the centuries, this type saw proliferation in those geographic areas where the climate allowed an outdoor domestic life all year. Thus, the typology is the crystallization of practical reasons in a formal idea. Its versatility is the reason for its exceptional popularity as a base unit in many Mediterranean cities.

The physiognomy of these cities is, in turn, a result of social structures defining the relations between the groups inhabiting them. For Islamic populations, organized by family hierarchies, urban agglomerations match a system that can be defined "introverted polycentric". In fact, generally, urban implants in this specific cultural arena are born from settlement processes involving several rural nomad tribes around a pole of interest. Each clan controls and manages its neighborhood by providing it with basic amenities such as a mosque, a madrasa, a fountain, a bakery and a hammam, to guarantee autonomy. Despite some changes over the centuries, the rural matrix of the urban space is what still characterizes every medina in Morocco. This aspect is even clearer if compared with the fact that here the urban courtyard house base unit, of a semi-rural origin, save for basic regional variations [7, 8], has survived virtually twelve centuries without substantial modifications. On other occasions, as in European cities, changes to socio-cultural structures have led to a gradual abandonment of the courtyard for an urban fabric that directly faces the streets ${ }^{11}$.

\footnotetext{
${ }^{10}$ The construction works were later finished by the French architects Auguste Cadet (Lyon 1881 - Casablanca 1956) and Edmond Brion (Soissons 1885 - Saint-Gervais 1973) over the following ten years.

${ }^{11}$ Between the 1970s and the 1980s, especially in Italy, a great deal of academic efforts were dedicated to study the transformation process of the domus type in Europe [9, 10].
} 


\section{Écochard's twofold strategy against Morocco's urban crisis}

Immediately after WWII, the eighth Resident-General, Erik Labonne ${ }^{12}$, appointed Michel Écochard ${ }^{13}$ director of the newly reformed territorial planning agency: the Service de l'Urbanisme. If, during those years, Morocco, spared by the war, was enjoying an economic boom, its industrial cities had by then exceeded their own demographic capacity. Écochard recognized that, to eradicate the problem, it would be necessary to operate on multiple fronts with a strategic plan based on understanding the local population's needs. His main concerns therefore became the successful dismantling of the bidonvilles, offering everyone respectable accommodation, and stemming the exodus from the country by providing rural centers with adequate infrastructure [14].

Écochard believed that the only possible answer to the chaos of Moroccan cities was a rational urban project aimed at defining the best housing conditions with the minimum possible use of means. To fathom the local dwelling dynamics, a large part of the Service's resources was used to collect data through local in-depth surveys. Because of the difficult road conditions, exploration of the remotest communities required considerable effort and lengthy timeframes. Consequently, the Service established a mobile study and design unit to act as a link between the central authority and the remoter regions: the Atelier Ambulant ${ }^{14}$. The countrywide data collected by the Service did not consider only quantitative issues, but rather, through drawings and photographic images, gave ample room to qualitative aspects of the urban, rural, and semi-rural structures, including the bidonvilles [17].

Through elaboration of these data, Écochard perfected the two pillars of his operative strategy: the unité de voisinage, a theoretical guide to new neighborhood schemes, and the $8 \times 8 \mathrm{~m}$ horizontal unité d'habitation, the base cell of the urban fabric $[14,18]$. These two principles showed his talent for drawing lessons from local traditions without cutting the link with the continuity of the Modern Movement. Indeed, if the structure of the unite de voisinage borrowed the configuration of the traditional city, seen as an aggregate of independent neighborhoods, it also was completely in line with American theories of the "Neighborhood Unit", developed by Clarence Perry ${ }^{15}$ in the late 1920s. Likewise, even the technique Écochard used to illustrate his idea closely recalled the propaganda with which, at the end of the $19^{\text {th }}$ century, Sir Ebenezer Howard ${ }^{16}$ promoted the virtues of the "Garden City". Similarly, the unité d'habitation derived from studies on types of traditional habitats, but the regional dwelling customs were depurated of their vernacular character to conform to a purely rational and Cartesian architectural language. The play of volumes given by the potentially infinite combination of units recalls aerial views of the medinas but is also the result of a need to cut construction costs by reducing street surface, repeating a prefabricated module, and using both sides of the same wall to build additional side-by-side units.

\footnotetext{
${ }^{12}$ Paris 1888-1971, French diplomat, Moroccan Resident-General in 1946 and 1947.

${ }^{13}$ Paris 1905-1985, French archaeologist, architect and urban planner. A vast literature is dedicated to his biography [11-13].

${ }^{14}$ Part of the findings of this unit were published $[1,15,16]$.

${ }^{15}$ Truxton (NY) 1872 - New Rochelle (NY) 1944, American planner and sociologist.

${ }^{16}$ London 1850 - Welwyn 1928, British urban planner.
} 


\section{The international discourse on architecture: "high-rise", "low-rise", and standardization}

Certainly, Écochard was not the first to deal with the theme of housing for the masses and its relationship with the design of the city. In a renowned article published in Das Neue Frankfurt in 1931, revealingly entitled "Flach-, Mittel- oder Hochbau?" [19], Walter Gropius $^{17}$ opened a never-concluded debate [20] by showing the preponderant advantages of the so-called "high-rise" popular building wherever high urban density had made a direct relationship between the housing unit and the land unsustainable. Over time, his assertions were followed by experimental designs for medium-low class districts to seek an alternative to the "high-rise" building, reconciling high urban density with a "low-rise" type that exploited the potential of the courtyard house. One of the most noticeable examples is Ludwig Hilberseimer's ${ }^{18}$ "House Type E" design, developed in 1931 for a new idea of a horizontal city. If this hypothesis clearly showed its purpose to exploit the repetition of the module to configure a certain relationship between public and private spaces, the thresholds of the accommodations communicated directly with the public space, and the internal distribution was completely disengaged from the courtyard, relegating the latter to the role of a mere backyard. Moreover, this spatial configuration forced each house to be paired with an access route, greatly reducing the chances of achieving high residential density. Analogous to this was the "horizontal city" design for the Corso Garibaldi neighborhood in Milan presented by Irenio Diotallevi, Franco Marescotti ${ }^{19}$ and Giuseppe Pagano ${ }^{20}$ in 1938. Here, compared to the previous design, both sides of the thoroughfares were used. This meant sequences of houses arranged in double rows, joined by a longitudinal wall that delimited the boundary between the courtyards of each residential unit. However, the rigid symmetry of the composition restricted the system to a forced North-South orientation, making this solution less than versatile for interventions in existing urban fabric. Moreover, also in this case, the modes of access and the disposition of the rooms relegated the courtyard to a secondary role.

\section{Écochard's invention of tradition}

Seeking common traits between the most current architectural theories ${ }^{21}$ and the peculiarities of the Moroccan context, Écochard entered this branch of the

\footnotetext{
${ }^{17}$ Berlin 1883 - Boston 1969, German architect, designer and urban planner, founder of the Bauhaus school. He is one of the fathers of the Modern Movement in architecture.

${ }^{18}$ Karlsruhe 1885 - Chicago 1967, German architect and urban planner, professor at Bauhaus and IIT.

${ }^{19}$ Respectively: Voltri 1909 - Milan 1954, Italian engineer and architect; Pesaro 1908 - Catania 1991, Italian architect.

${ }^{20}$ Parenzo 1896 - Mauthausen 1945, Italian architect, editor in chief of the Italian architectural magazine Casabella from 1931 until 1943. He is considered one of the fathers of Italian Razionalismo.

${ }^{21}$ Écochard was in close contact with many of the major players in the modern international architectural debate. In 1945, he participated, together with Le Corbusier and Vladimir Bodiansky, in a mission to the United States to study the social policies of the Tennessee
} 
international debate by inventing ${ }^{22}$ a minimal residential unit that finally took full advantage of the courtyard giving it the role of a genuine open-air room. In fact, the typological device conceived used the courtyard both as a filtering space between the street and the intimacy of the interiors, and as a distributive nucleus between the latter. Moreover, the configuration enabled the units to be positioned to define a frame and not just simple rows. This made it possible to better exploit the ground using more compact blocks, but without compromising the solar exposure. The simple effectiveness of Écochard's frame was so successful in Morocco that it became the matrix of all economic construction plans until the $1980 \mathrm{~s}^{23}$ [17]. Écochard, however, perhaps to avoid being accused of opposing progress at a time when the dominant international thought snubbed such terms as "tradition", tended to underline the "evolutive" nature of his frame. In fact, in his writings, he claimed that this configuration was nothing but the first of a series of typological metamorphoses which, ending with the construction of multi-story houses, would gradually accustom new citizens to modern apartment living [14].

\section{The international influence of Écochard's work}

The relevance of Écochard's work becomes even more visible by comparison with that of the protagonists of the post-war Modern Movement. In 1951, Sigfried Giedion $^{24}$ invited the director of the Service to participate in the $8^{\text {th }}$ CIAM at Hoddesdon. Attending as "independent", the French architect presented the plan for the industrial satellite district of Yacoub el Mansour [21, 24, 25]. This project expounded his theoretical thinking, combining the circulation and zoning principles of the Athens Charter, the logic of neighborhood units and the urban center, the application of the housing frame, and a desire to provide rural centers with modern amenities [14]. On this occasion, Josep Lluís Sert ${ }^{25}$ - CIAM president since 1947 and Paul Lester Wiener ${ }^{26}$, showed their proposals for the industrial city of Chimbote, in Peru, developed over the previous three years. Although it is difficult to think that the two works had influenced each other, what is striking is not so much the fact that this plan also respected the provisions of the Athens Charter, but that both projects tried to find contemporary versions of the traditional popular courtyard house. The truth is that the analogies between the two proposals brought to the surface what were still covert traces of an imminent change of course within the dominant thought of the Modern Movement.

\footnotetext{
Valley Authority. On this occasion, he met Sigfried Giedion who, in 1947, invited him to form a Moroccan group to participate in the 1951 CIAM in Bergamo [21, 22].

${ }^{22}$ The term "invention" is here interpreted in its etymological meaning as "discovering through research".

${ }^{23}$ Actually, the model was widely used throughout North Africa: e.g. between 1954 and 1960, in Algeria, the French architects Lathuillère, Di Martino, and Serro, used a slightly modified Écochard's unité d'habitation to build 200 houses as a part of Orléansville's reconstruction plan, after the Chlef earthquake [23].

${ }^{24}$ Prague 1888 - Zurich 1968, German-Swiss historian and critic of architecture. Along with Le Corbusier and Hélène de Mandrot was one of the founding members of the CIAM.

${ }^{25}$ Barcelona 1902-1983, Catalan architect and urban planner, co-founder of the GATCPAC.

${ }^{26}$ Leipzig 1895 - Munich 1967, German-American architect and urban planner.
} 
The rifts would reveal themselves in all their ideological depth just two years later, at the $9^{\text {th }}$ CIAM in Aix-en-Provence dedicated, after vehement requests by a group of "young members", to the theme of the Habitat ${ }^{27}$. On this occasion, Écochard ${ }^{28}$, as head of the GAMMA ${ }^{29}$, was finally able to show the world the extent of the research carried out by his office over the previous seven years. Through graphs, drawings, reliefs and, above all, photographs, the Moroccan grids dubbed "I'Habitat pour le plus grand nombre" demonstrated the potential of a method that combined rigorous scientific abstraction with empathy towards the tradition and soul of a place.

The spread of Écochard's thought did not remain solely within the CIAM. In 1951, the Italian architect Adalberto Libera ${ }^{30}$ participated in the $2^{\text {nd }}$ Congress of the International Union of Architects in Rabat ${ }^{31}$, where he encountered the work of Écochard, who was general speaker at the event. His stay in Morocco profoundly affected Libera who, on his return, would concretize this experience in his conception of the Tuscolano district in Rome. The principle that guided him was an adhesion "to the character of the Mediterranean life as a function of living" [28]. The group of single-family courtyard houses, organized around a central space separated from the street by a social services building, was the result of his desire to rediscover an idea of community. The architect divided the L-shaped buildings, of 5, 6 or 7 rooms, into groups of four units, orienting three of the courtyards towards the inside of the composition, and inverting the house southwards to prevent the rooms overlooking the courtyard from facing north. This solution allowed access from the courtyard only to the latter apartment while, for the other three, the central open space reverted to a simple backyard. However, the gradual transition from public to private life was ensured by the concentric organization of the whole block.

Variations on the theme were conceived within the same Moroccan context when, while rebuilding Agadir after the 1960 earthquake [29], Jean-François Zevaco ${ }^{32}$ was tasked with designing a residential complex for civil servants $(1964)^{33}$. In this case, the courtyard was no longer a single central element but was divided into a paratactic sequence of spaces designed to illuminate and ventilate each room individually. From the outside, the two blocks appear as enclosures, rhythmically interrupted by the gates to the dwelling units. Beyond the perimeter wall, before entering the house, is a filter courtyard onto which only small fixed windows and the entrance door face. The latter overlooks a small atrium that preludes the living room, kitchen, and corridor to the sleeping area. The living room is a rectangle that communicates with the larger courtyard at the rear of the house. The kitchen extends outdoors through its own service courtyard. The spaces are arranged so that both sides of each bedroom face smaller private courts, to maximize solar exposure. Although it is clear that the houses, in this case, are

\footnotetext{
${ }^{27}$ Écochard was also involved in the process of drafting the so-called Charter of Habitat [26].

${ }^{28}$ The urban planner had been discharged from office in Morocco for one year.

${ }^{29}$ Groupe des Architectes Modernes Marocains. Organized by Georges Candilis; in 1953, the group had fifteen members [27].

30 Villa Lagarina 1903 - Roma 1963, Italian architect. He is considered among the major exponents of the Razionalismo.

31 The congress was titled "How Architecture is Dealing with its New Tasks".

${ }^{32}$ Casablanca 1916-2003, French-Moroccan architect, member of the GAMMA. My doctoral thesis [30] is dedicated to a part of his work [31-33].

${ }^{33}$ In 1980, the residential complex was awarded the Aga Khan Prize for Architecture [34].
} 
destined for middle-high classes, the typological transformation carried out by Zevaco shows a change in the basic cell of Moroccan society: the family. Indeed, the new layout of the spaces, although still seeking a condition of total privacy for the household, is open to the idea that domestic reality is also made up of spaces that let all the family members enjoy their individuality.

Écochard's direct or transversal influence on the new generation of modern architects became evident when, in 1968, the British architect Peter Land ${ }^{34}$ was commissioned by the UN to coordinate an international competition by invitation for the construction of an experimental neighborhood of 500 lodgings in Lima, to stem the problem of the barriadas: the Proyecto Experimental de Vivienda (PREVI) [35, 36]. The competition guidelines required participants to design a neighborhood based on the idea of a modular repetition of high-density courtyard houses, designed to grow over time and be a model for future expansions [37]. Land selected twentysix groups, of which thirteen were Peruvian. These local architects had trained under the influence of Sert and Wiener: many of them were members of the Departamento de Arquitectura de l'Universidad Nacional de Ingeniéria, the first true Peruvian school of architecture, strongly associated with the CIAM, others had been members of the Agrupaciòn Epsacio, the Peruvian chapter of the Congresses. Among the international architects, Aldo van Eyck, Oskar Hansen, and Georges Candilis ${ }^{35}$ were members of Team $\mathrm{X}^{36}$, James Stirling, Charles Correa, Fumihiko Maki and Christopher Alexander ${ }^{37}$ were known to be linked to the ascendancy of the CIAM [21]. The anomalous aspect of this competition was that, overturning the jury's decision, it was decided to assign twenty-six first prizes and to let each group realize one block. The result, although virtually incomplete, is perhaps the last extraordinary proof of the versatility of the modular courtyard house in constructing a city.

\section{Conclusions}

The social changes affecting the West after 1968, with the decline of the patriarchal family, may have been one of the main causes of the gradual loss of interest in the popular courtyard house in the international architectural debate ${ }^{38}$. It should however be stressed that, although any reference to studies on traditional rural dwellings has now waned, the influences of Écochard's work still surface in all those recent projects that have exploited the compositional expedient of the "frame" [41-42] and,

\footnotetext{
${ }^{34}$ Norwich n.d., British architect.

${ }^{35}$ Respectively: Driebergen 1918 - Loenen 1999, Dutch architect; Helsinki 1922 - Warsaw 2005, Polish architect; Baku 1913 - Paris 1995, Greek-French architect.

${ }^{36}$ The members of Team $X$ had always declared themselves deeply impressed by the work of the GAMMA exhibited at the CIAM in Aix-en-Provence [21, 25, 38-40].

37 Respectively: Glasgow 1926 - London 1992, British architect; Secunderabad 1930 Mumbai 2015, Indian architect; Tokyo 1928, Japanese architect; Wien 1936, Austrian architect.

${ }^{38}$ Without doubt it is also true that, on the one hand, with time, there have been fewer public initiatives concerning mass housing and that, on the other, the prevailing of economic needs over aesthetic ones has, in the end, brought public administrations to favor high density projects and low land consumption.
} 
especially in developing countries, in that cutting-edge thinking which tests the spontaneous evolutionary potential of an open-ended architectural design ${ }^{39}$.

\section{Short resume}

Edoardo Bernasconi was born in Milan in 1986 and in 2012 graduated in Architecture from the School of Civil Architecture at the Politecnico di Milano. Since 2012, he has been collaborating in several university courses at the School of Architecture, Urban Planning and Construction Engineering at the Politecnico di Milano, and also lecturing in Milan, Turin, Venice and Naples. In 2016, he discussed his PhD thesis in Architectural Composition, Verso un'antica lingua moderna. La città di Agadir e l'opera di Jean-François Zevaco, at the IUAV University of Venice. From 2018, he is a guest lecturer at the Politecnico di Milano.

\section{References}

1. MAURET, É. 1955. "Problèmes de l'équipement rural dans l'aménagement du territoire", L'Architecture d'Aujourd'hui, n 60: 42-45.

2. ESTIENNE, I. 2011. “L'aménagement comme stratégie professionnelle. L'exemple de cinq paysagistes formés à la section du paysage et de l'art des jardins de Versailles en 1946-1948", Projets de paysage. Retrieved from: http://www.projetsdepaysage.fr/fr/l_amenagement_comme_strategie_professi onnelle [available 10 June 2018].

3. DETHIER, J. 1970. "Soixante ans d'urbanisme au Maroc. L'évolution des idées et des réalisations", Bulletin Économique et Social du Maroc, $\mathrm{n}^{\circ}$ 118-119: 5-56.

4. SUISSE, P. 1956. "L'exode rural", Bulletin Économique et Social du Maroc, $\mathrm{n}^{\circ}$ 68: 459-467.

5. COHEN J.-L.; ELEB M. 1998. Casablanca. Mythes et figures d'une aventure urbaine, Paris, Hazan.

6. ELEB, M. 2010. "Interiorized Exterior: The Courtyard in Casablanca's Public and Company Housing (1910-60)", in N.O. Rabbat (ed.), The Courtyard House. From Cultural Reference to Universal Relevance, London, Ashgate: 101-118. DOI: https://doi.org/10.4324/9781315086866-6

7. BIANCA, S. 2000. The Urban Form in the Arab World: Past and Present, New York, Thames \& Hudson.

8. PETRUCCIOLI, A. 2006. "The Courtyard House: Typological Variations over Space and Time", in B. Edwards, M. Sibley, M. Hakmi et al. (eds.), Courtyard Housing. Past, Present and Future, Abingdon-New York, Taylor \& Francis: 320. DOI: https://doi.org/10.4324/9780203646724-11

9. CANIGGIA, G. (1973) 1981. "La casa-corte: definizione, diffusione, origini ed accezione comense", in Id., Struttura dello spazio antropico. Studi e note, Florence, Alinea: 13-62.

10. CANIGGIA, G. 1986. "La casa e la città dei primi secoli”, in P. Maretto, La casa

${ }^{39}$ For example, the projects designed by ELEMENTAL of the Chilean architect Alejandro Aravena, Pritzker Prize in 2016. 
veneziana nella storia della città dalle origini all'Ottocento, Venice, Marsilio: 552.

11. Articles et mémoires. Hommage à Michel Écochard (1990). Paris, Paul Geuthner.

12. VERDEIL, E. 2012. "Michel Écochard in Lebanon and Syria (1956-1968). The Spread of Modernism, the Building of the Independent States and the Rise of Local professionals of planning", Planning Perspective, vol. 27, $n^{\circ}$ 2: 249-266. DOI: https://doi.org/10.1080/02665433.2012.646774

13. AVERMAETE, T. 2014. "Michel Écochard (1905-1985)", in Id.; M. Casciato, Casablanca Chandigarh. A Report on Modernization, Montréal-Zürich, CCAPark Books: 91-92.

14. ÉCOCHARD M. 1950. "Urbanisme et construction pour le plus grand nombre", Annales de l'Institut Technique du Bâtiment et des Travaux Publics, n 148: 112 [republ. as ID. 1951. "Problèmes d'Urbanisme au Maroc", Bulletin Économique et Social du Maroc, $\mathrm{n}^{\circ}$ 52: 28-35].

15. MAS, P. 1954. "Problèmes d'habitat musulman au Maroc", Bulletin Économique et Social du Maroc, $\mathrm{n}^{\circ}$ 62: 201-208.

16. MAURET, É. 1954. "Problème de l'habitat rural dans la région de Rabat", Bulletin Économique et Social du Maroc, $\mathrm{n}^{\circ}$ 64: 587-599.

17. AVERMAETE, T. 2010. "Framing the Afropolis. Michel Écochard and the African City for the Greatest Number", OASE, $\mathrm{n}^{\circ}$ 82: 77-99. Retrieved from https://www.oasejournal.nl/en/lssues/82/FramingTheAfropolis [available on 29 January 2019].

18. ÉCOCHARD, M. 1955. "Habitat Musulman au Maroc", L'Architecture d'Aujourd'hui, n 60: 36-39.

19. GROPIUS, W. 1931. "Flach-, Mittel- oder Hochbau?", Das Neue Frankfurt, vol. 5, $\mathrm{n}^{\circ}$ 2: 22-34.

20. GIURA LONGO, T. 1975. "Contributi italiani al tema dell'unità d'abitazione / The Italian Contribution to the Residential Neighborhood Design Concept", Lotus, $\mathrm{n}^{\circ}$ 9: 62-75, 213-216.

21. COHEN, J.-L. 1992. "Il Gruppo degli Architetti Marocchini e 'L'Habitat du plus grand nombre'", Rassegna, ${ }^{\circ}$ 52: 58-67.

22. AVERMAETE, T. 2015. "From Knoxville to Bidonville: ATBAT and the Architecture of the French Welfare State", in Id.; M. Swenarton; D. van den Heuvel, Architecture and the Welfare State, Abingdon-New York, Routledge: 219-236. DOI: https://doi.org/10.4324/9781315766928-18

23. DE MAISONSEUL, J. 1955, "La reconstruction des regions sinistrées par le séisme du Chéliff", L'Architecture d'Aujourd'hui, $\mathrm{n}^{\circ}$ 60: 14-21.

24. TYRWHITT, J.; SERT, J.L.; ROGERS, E.N. 1952. The Heart of the City: Towards the Humanization of Urban Life, New York, Pellegrini \& Cudahy.

25. MUMFORD, E. 2002. The CIAM Discourse on Urbanism. 1928-1960, Cambridge-London, MIT Press.

26. ÉCOCHARD, M. (1953) 1979, "Habitat pour le plus grande nombre. Position du probème par rapport à la Charte de l'Habitat", in V. Bodiansky (ed.), CIAM 9 , 
Aix-en-Provence - 19-25 Juillet 1953, Contribution à la Charte de l'Habitat, Nendeld, Kraus Reprint.

27. CHAOUNI A. 2011. "Depoliticizing Group GAMMA: contesting modernism in Morocco", in D. Lu (ed.), Third World Modernism. Architecture, Development and Identity, London-New York, Routledge: 57-84. DOI: https://doi.org/10.4324/9780203840993-9

28. ZANUSO, M. 1955. "Adalberto Libera. Unità d'abitazione orizzontale nel quartiere Tuscolano a Roma", Casabella-continuità, n² 207: 30.

29. BERNASCONI, E.L.G. 2017. "Reconstruction and Identity. The Case Study of Agadir's Earthquake”, Urbanistica Informazioni (Special issue: Proceedings of the $10^{\circ}$ INU Study Day "Crisis and rebirth of Cities", Naples, 15 December 2017), vol. 41, $\mathrm{n}^{\circ} 272$ s.i.: 137-142. Retrieved from: http://www.urbanisticainformazioni.it/IMG/pdf/ui_272si_02_sessione_02.pdf [available on 29 January 2019].

30. BERNASCONI, E.L.G. 2016. Verso un'antica lingua moderna. La città di Agadir e l'opera di Jean-François Zevaco, PhD dissertation, IUAV University of Venice.

31. RAGON, M.; TASTEMAIN, H. 1999. Zevaco, Paris, Cercle d'Art.

32. "Architecture marocaine contemporaine: J.-F. Zevaco" (1964), a+u - Revue africaine d'architecture et d'urbanisme, $\mathrm{n}^{\circ}$ 1: 12-22.

33. HOFBAUER, L. 2010. "Transferts de modèles architecturaux au Maroc. L'exemple de Jean-François Zévaco, architecte (1916-2003)", Les Cahiers d'EMAM, n² 20: 71-86. DOI: https://doi.org/10.4000/emam.77

34. HOLOD, R. (ed.) 1983. Architecture and Community. Building in the Islamic World Today, London, Islamic Publications: 89-96.

35. GARCÍA-HUIDOBRO, F.; TORRES TORRITI, D.; TUGAS, N. 2008. ;EI Tiempo Construye! Time Builds!, Barcelona, Gustavo Gili.

36. MCGUIRK, J. 2011. "PREVI. The Metabolist Utopia", Domus, n 946: 58-71. Retrieved from: https://www.domusweb.it/en/architecture/2011/04/21/previthe-metabolist-utopia.html [available on 29 January 2019].

37. KAHATT, S.S. 2011. "Agrupación Espacio and the CIAM Peru Group: Architecture and the City in the Peruvian Modern Project", in D. Lu (ed.), Op.cit.: 85-110. DOI: https://doi.org/10.4324/9780203840993-10

38. ELEB, M. 2000. "An Alternative to Functionalist Universalism: Écochard, Candilis and ATBAT-Afrique", in S. Williams Goldhagen, R. Legault (eds.), Anxious Modernism: Experimentation in Postwar Architectural Culture, Montréal-Cambridge, CCA-MIT Press: 55-73.

39. AVERMAETE, T. 2010. "Nomadic Experts and Travelling Perspective: Colonial Modernity and the Epistemological Shift in Modern Architectural Culture", in Id., S. Karakayali, M. von Osten (eds.), Colonial Modern. Aesthetics of the Past Rebellions for the Future, London, Black Dog Publishing: 130-149.

40. AVERMAETE, T. 2009. "CIAM, Team X, and the Rediscovery of African Settlements. Between Dogon and Bidonville", in J.-F. Lejeune, M. Sabatino (eds.), Modern Architecture and the Mediterranean. Vernacular Dialogues and Contested Identities, London-New York, Routledge: 251-264. DOI: 
https://doi.org/10.4324/9780203871904-22

41. SMITHSON, A. 2001. "How to Recognize and Read Mat-Building. Mainstream Architecture as it Has Developed towards the Mat-Building", in H. Sarkis (ed.), CASE: Le Corbusier's Venice Hospital and the Mat Building Revival, MunichLondon-New York, Prestel Verlag: 90-103.

42. HYDE T. 2001. "How to Construct an Architectural Genealogy. Mat-Building... Mat-Buildings... Matted-Buildings", in H. Sarkis (ed.), Op. cit.: 104-117.

43. OXMAN, R.; SHADAR, H.; BELFERMAN E. 2002. "Casbah: a brief history of a design concept”, arq: Architectural Research Quarterly, vol. 6, n 4, p. 321-336. DOI: https://doi.org/10.1017/S1359135503001854 